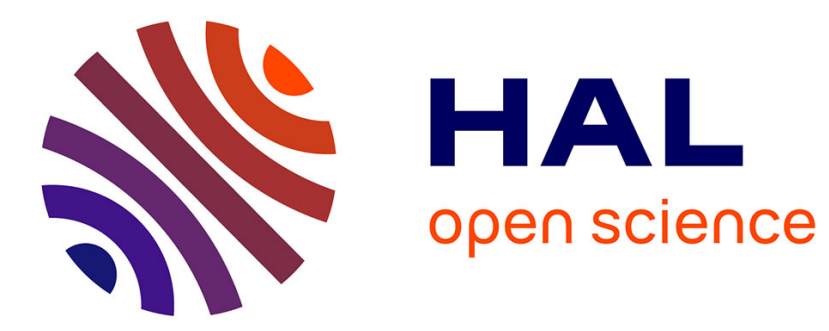

\title{
Dynamics of sheet nacre formation in bivalves
}

Marthe Rousseau, Anders Meibom, Marc Gèze, Xavier Bourrat, Martine Angellier, Evelyne Lopez

\section{To cite this version:}

Marthe Rousseau, Anders Meibom, Marc Gèze, Xavier Bourrat, Martine Angellier, et al.. Dynamics of sheet nacre formation in bivalves. Journal of Structural Biology, 2009, 165 (3), pp.190-195. 10.1016/j.jsb.2008.11.011 . insu-00371791

\section{HAL Id: insu-00371791 https://hal-insu.archives-ouvertes.fr/insu-00371791}

Submitted on 1 Apr 2009

HAL is a multi-disciplinary open access archive for the deposit and dissemination of scientific research documents, whether they are published or not. The documents may come from teaching and research institutions in France or abroad, or from public or private research centers.
L'archive ouverte pluridisciplinaire HAL, est destinée au dépôt et à la diffusion de documents scientifiques de niveau recherche, publiés ou non, émanant des établissements d'enseignement et de recherche français ou étrangers, des laboratoires publics ou privés. 


\title{
Dynamics of sheet nacre formation in bivalves
}

\author{
Marthe Rousseau ${ }^{\mathrm{a},}$ Anders Meibo ${ }^{\mathrm{b}}$ Marc Gèze $^{\mathrm{c}}$, Xavier Bourrat ${ }^{\mathrm{d}}$, Martine Angellier ${ }^{\mathrm{d}}$ \\ and Evelyne Lopez
}

${ }^{a} U M R 7561$ CNRS-Nancy University, BP 184, 54505 Vandoeuvre les Nancy, France

${ }^{\mathrm{b}}$ National Museum of Natural History, LEME, 61, rue Buffon, 75005 Paris, France

${ }^{\mathrm{c}}$ National Museum of Natural History, USM 504, 61, rue Buffon, 75005 Paris, France

${ }^{\mathrm{d}}$ Université d'Orléans, Université François Rabelais - Tours, CNRS/INSU

Institut des Sciences de la Terre d'Orléans - UMR 6113

Campus Géosciences - 1A, rue de la Férollerie 45071 Orléans cedex 2 France

${ }^{\mathrm{e}}$ National Museum of Natural History, BOME, 43 rue Cuvier, 75005 Paris, France

\begin{abstract}
Formation of nacre (mother-of-pearl) is a biomineralization process of fundamental scientific as well as industrial importance. However, the dynamics of the formation process is still not understood. Here, we use scanning electron microscopy and high spatial resolution ion microprobe depth-profiling to image the full three-dimensional distribution of organic materials around individual tablets in the top-most layer of forming nacre in bivalves. Nacre formation proceeds by lateral, symmetric growth of individual tablets mediated by a growthring rich in organics, in which aragonite crystallizes from amorphous precursors. The pivotal role in nacre formation played by the growth-ring structure documented in this study adds further complexity to a highly dynamical biomineralization process.
\end{abstract}

Keywords: Biomineralization; Calcium carbonate; Nacre; SEM; SIMS

\section{Introduction}

Nacre, or mother-of-pearl, is an aragonite-dominated structure produced by bivalves, gastropods, and cephalopods as an internal coating of their otherwise calcitic shells. Because of its highly organized internal structure, chemical complexity, mechanical properties and optical effects, which create a characteristic and beautiful lustre, the formation of nacre is among the best-studied examples of calcium carbonate biomineralization ([Wada, 1961], [Bevelander and Nakahara, 1969], [Mutvei, 1979], [Lowenstam, 1981], [Levi-Kalisman et al., 2001], [Currey, 2005], [Snow and Pring, 2005] and [Addadi et al., 2006]). The high-strength mechanical properties of nacre and the fact that the world pearl jewellery represents a global market worth about 5 billions US\$ annually (Anon, 2006) have prompted efforts to mimic nacre formation by industrial processes (Addadi et al., 2006). Such efforts require a high level of understanding of the biochemistry and the growth dynamics of nacre formation in nature.

Among the nacre-forming organisms, great diversity is observed with regard to the threedimensional arrangement of this highly organized structure (Mutvei, 1979). This structural diversity implies substantial variation in the process of nacre formation among different organisms. Here we focus on nacre structure and formation in the pearl-producing bivalve 
Pinctada margaritifera. Fig. 1 shows the characteristic brick-and-mortar structure of the nacreous layer in P. margaritifera. The primary structural component of mature nacre is a pseudohexagonal tablet, about $0.5-1$ micrometer $(\mu \mathrm{m})$ thick and about $5-10 \mu \mathrm{m}$ in width, consisting primarily of aragonite: a polymorph of $\mathrm{CaCO}_{3}$. At the nanometer $(\mathrm{nm})$ length scale, the aragonite component inside individual tablets is embedded in a crystallographically oriented foam-like structure of intra-crystalline organic materials in which the mean size of individual aragonite domains is around $50 \mathrm{~nm}$, ([Rousseau et al., 2005a] and [Stolarski and Mazur, 2005]). The crystallographic properties of nacre are that of single crystal aragonite with the $c$-axis oriented perpendicular to the plane defined by individual tablets. Locally, the $a$ and $b$ axes in the plane of the tablet layers show long-range (i.e. mm-scale) orientation but can also be rotated differently (up to about $45^{\circ}$ ) around the $c$-axis in different parts of the shell ([Wada, 1958], [Weiner and Addadi, 1997], [Caseiro, 1995], [Checa and Rodriguez-Navarro, 2005], [Rousseau et al., 2005a] and [Checa et al., 2006]). It is thought that crystallographic orientations are defined by the inter-lamellar, foam-like network of organic material and transferred from tablet to tablet by 'bridges' of similar material (Rousseau et al., 2005a). (Checa and Rodriguez-Navarro, 2005) and (Checa et al., 2006) have suggested a model for how crystal orientation is established in sheet nacre, in which the $b$-axis becomes gradually aligned with the radial nacre growth direction. In any case, mature tablets are organized in layers in which each tablet is in physical contact with its neighbour, only separated by a $\mathrm{nm}$ thick, inter-tabular matrix consisting primarily of aragonite-nucleating proteins and carboxylates, ([Addadi et al., 2006], [Nudelman et al., 2006] and [Dauphin et al., 2008]). Individual layers of tablets are separated by a 50-100 nm layer consisting mainly of chitin and organic material (Levi-Kalisman et al., 2001). This is the inter-lamellar matrix. Several layers of nacre tablets form at the same time across a growth front, with subsequent layers arranged as 'stair-cases' in which each step is typically 10-15 $\mu \mathrm{m}$ wide, (Rousseau et al., 2005b). In this way, up to 3-4 layers of nacre tablets are formed per day (Caseiro, 1995). It has been established that nacre tablet formation takes place in the space defined by the two-top layers of inter-lamellar matrix (Bevelander and Nakahara, 1969). We refer to the layer of organics that separates the animal from the growing nacre as the 'membrane'. This highly cross-linked protein-rich membrane (Nudelman et al., 2008) is in direct contact with the epithelial cellstructure of the overlying organism, which is referred to as the 'mantle' (Fig. 1). In the space beneath the membrane, tablets growth proceeds from nucleation sites, which are complex structures consisting of different layers of organic molecules (Nudelman et al., 2006). The distribution of nucleation sites is dictated by the geometry of the underlying layer of tablets, each nucleation site is often situated above a triple-junction of underlying tablets (Rousseau et al., 2005b). The mantle delivers specific organic molecules (including proteinaceous materials - the so-called 'silk-phase') and carbonate components to the closed compartment between the membrane and the first inter-lamellar matrix-layer, which was the top membrane during the formation of the previous layer of nacre tablets (Bevelander and Nakahara, 1969). It has been speculated that growth of individual nacre tablets occur by nucleation and crystallization of amorphous calcium carbonate (ACC) (Towe and Hamilton, 1968). However, because our knowledge about the formation of the nacre structure is largely based on studies of mature nacre structures, little is known about the growth dynamics of individual tablets. The small dimensions of the closed compartment, in which nacre formation takes place (Bevelander and Nakahara, 1969), and the tight physical relationship between the growing nacre structure and the mantle render direct studies difficult. Here, we circumvent these difficulties with a simple preparation technique and by applying new ion microprobe technology to the study of developing nacre tablets prepared with a minimum of alteration of inter-lamellar and intertablet organics. 


\section{Materials and methods}

We have studied six month old P. margaritifera oysters grown in their natural habitat, at depths of 7-12 m, under carefully monitored conditions at the Marine Station of Marutea in French Polynesia. The animals were fixed with ethanol initially at $70 \mathrm{vol} \%$. The water content was gradually decreased in increasingly ethanol-rich solutions ( 3 day baths in $80 \%, 90 \%$, and $100 \%$ ethanol, respectively) and, after complete dehydration, the shells were opened, allowing the soft tissue of the mantle to be separated from the growing nacre precisely at the top surface of the membrane that separates the surface of the growing nacre from the mantle, allowing a study of the interface between the mantle and the shell (see Supplementary Material, SM). The sample was then dried by air. This preparation, which preserves even the most delicate structures of the membrane and the nacre surface (Figs. S1 and S2), reveals several important aspects of nacre growth dynamics. After gold coating, observations were performed at the Common Service of Electronic Microscopy of the laboratories of the Life Sciences, National Museum of Natural History (France) with a JEOL JSM-840A scanning electron microscope (SEM) operating at $15 \mathrm{kV}$. Following SEM observations, the samples were analyzed by the NanoSIMS in order to image the distribution of elements primarily associated with organic materials in the top-most layer of the growing nacre structure.

NanoSIMS: Using a focused (primary) beam of $\mathrm{Cs}^{+}$with a current of $\sim 1 \mathrm{pA}$ on the sample, secondary ions were sputtered from the sample surface. Ions of hydrogen $\left(\mathrm{H}^{-}\right)$, nitrogen $(\mathrm{N}$, measured as $\left.{ }^{12} \mathrm{C}^{14} \mathrm{~N}^{-}\right)$and sulfur $\left({ }^{32} \mathrm{~S}^{-}\right)$were detected simultaneously (multicollection-mode) in electron-multipliers at a mass-resolving power of $\sim 4000(\mathrm{M} / \Delta \mathrm{M})$. At this mass-resolving power, the measured secondary ions are resolved from potential molecular interferences. During $\mathrm{Cs}^{+}$bombardment, charge compensation was achieved by simultaneous delivery of electrons to the surface. Note that because $\mathrm{N}$ is measured as the ${ }^{12} \mathrm{C}^{14} \mathrm{~N}^{-}$ion detection of $\mathrm{N}$ can only be made from regions containing carbon. However, because the nacre structure consists primarily of $\mathrm{CaCO}_{3}$ and organic matter there are no regions in which carbon is not available to generate the ${ }^{12} \mathrm{C}^{14} \mathrm{~N}^{-}$ion. Thus the variations recorded in ${ }^{12} \mathrm{C}^{14} \mathrm{~N}^{-}$are representative of variations in the $\mathrm{N}$ concentration across the imaged structures. Images were obtained from a pre-sputtered surface by rastering the primary ions across the sample surface.

\section{Results and discussion}

Fig. 2 shows the surface membrane, observed from the point of view of the nacre layer, and corresponding features in the growing nacre surface, respectively. Several important observations can be made. (i) For each nacre tablet, there exists in the membrane a circular structure (Fig. 2A and C). The circular membrane structure displays higher topography than the adjacent surface membrane. We refer to this circular structure as the 'ring'. (ii) This ring makes direct physical contact with the growing nacre tablets. Each nacre tablet features a similar ring, several hundred $\mathrm{nm}$ wide, with a complementary (i.e. lower) topography (Fig. $2 \mathrm{~B}$ and D). (iii) Neighbouring tablets can merge during growth by lateral expansion that leads to a 'collision'. In this process, ring structures surrounding each tablet first merge together, then disappear (Fig. 2D). Similarly, the ring structures in the membrane first merge and then disappear in the membrane during tablet collision (Fig. 2C).

These structural observations raise questions about the compositional properties of the ring around individual nacre tablets, which clearly plays an essential role in the growth process. Because the growing tablets are forming in a closed compartment underneath the membrane (Fig. 1 and Fig. 2), direct chemical analysis is problematic. We circumvent these difficulties 
by taking advantage of recently developed ion microprobe technology, the NanoSIMS. The NanoSIMS allows chemical composition to be imaged with extremely high spatial resolution (on the order of $100 \mathrm{~nm}$ ), while depth-profiling through the inter-lamellar matrix and into the nacreous structure with a depth resolution of about $10 \mathrm{~nm}$ per image ([Meibom et al., 2004] and [Meibom et al., 2007]). The 3-dimensional distribution of $\mathrm{H}, \mathrm{N}$ and $\mathrm{S}$ are diagnostic of organic compounds in which their concentration is greatly increased over that in the aragonitic nacre tablets. Fig. 3A shows the 3-D reconstruction of a depth-sequence of $\mathrm{H}$ images from the top-most layers (in the membrane), via intermediate levels to an estimated depth of around $0.2 \mu \mathrm{m}$ in the tablet structure, where the overlying membrane has been sputtered away completely and the distribution of organics around individual tablets becomes visible; see SD for 3-dimensional reconstructions of the corresponding $\mathrm{N}$ and $\mathrm{S}$ distributions. The distribution of organics in the ring surrounding each nacre tablet corresponds to the characteristic ring in the overlying mantle; see Fig. 2D. Fig. 3C shows in greater detail the distribution of organics around individual tablets. Importantly, concentrations of $\mathrm{H}, \mathrm{N}$ and $\mathrm{S}$ are clearly confined to the rim around each tablet. In the ring, the signal from $\mathrm{N}$ is almost two orders of magnitude higher than in the surrounding aragonitic tablets. Sulfur and Hydrogen are enriched by factors of about 10 and 7, respectively over the signal observed from inside the tablet. The ring structures are flat structures (Fig. 2) and completely resolved by the primary beam of the NanoSIMS, indicating that the enhanced concentrations in $\mathrm{H}, \mathrm{N}$ and $\mathrm{S}$ cannot be ascribed to topographic, i.e. edge effects. The observations demonstrate that the ring around individual aragonite tablets is a 3-dimensional structure that is greatly enriched in organic molecules. Good candidates for these compounds are carboxylates, sulphated sugars, and aragonite-nucleating proteins, which also characterize the nucleation sites and the thin inter-tabular matrix separating mature tablets ([Addadi et al., 2006], [Nudelman et al., 2006] and Nudelman et al., 2008 F. Nudelman, E. Shimoni, E. Klein, M. Rousseau, X. Bourrat, E. Lopez, L. Addadi and S. Weiner, Environmental- and cryo-scanning electron microscopy study of the forming nacreous layer from the shells of the bivalves Atrina rigida and Pinctada margaritifera, J. Struct. Biol. 162 (2008), pp. 290-300; The high content of $\mathrm{N}$ in the ring is consistent with the presence of aragonite-nucleating proteins (Nudelman et al., 2006).

From these observations, we propose that the nacre tablet formation takes place via the formation of a growth-ring that surrounds each tablet (Fig. 2 and Fig. 3). This model is illustrated in Fig. 4. The proposed model is built on several recent observations, in combination with those presented here. It has been established that nacre tablet formation proceeds from a hydro-gel loaded with calcium carbonate precursor material, acidic proteins and the silk-phase (Addadi et al., 2006). The acidic proteins in the hydro-gel can either inhibit calcium carbonate crystallization, as demonstrated by in vitro experiments or stimulate aragonite crystallization, depending on the nature of the locally dominating acidic protein fraction ([Cohen, 2003] and [Addadi et al., 2006]). Polyclonal antibody labelling of aragonitenucleating acidic proteins has shown that a specific component of the acidic protein fraction is concentrated in the nucleation sites, which initiate the formation of individual nacre tablets (Nudelman et al., 2006). These nucleation sites are in the majority of cases situated at a triplejunction of three nacre tablets in the previously formed layer (Fig. 4) and are therefore supposed to be inherited by mechanical transfer of material displaced upward during nacre tablet collision in the layer below. Once aragonite nucleation is triggered at these nucleation sites, the growth of the nacre tablet proceeds upward to fill the space between the membrane and the underlying inter-lamellar matrix, then laterally until collision with neighbouring tablets take place (Fig. 4). The bulk of this growth phase is mediated by the growth-ring exhibited in Fig. 2 and Fig. 3. The calcium carbonate precursor is most likely amorphous ([Istin and Girard, 1970] and [Addadi et al., 2003]) consistent with the observation of a thin 
(about $5 \mathrm{~nm}$ ) veneer of amorphous calcium carbonate (ACC) surrounding mature nacre tablets ([Gehrke et al., 2005] and [Nassif et al., 2005]). In contrast, the end-product in bulk nacre tablets is crystallographically oriented aragonite crystals with an average size around $50 \mathrm{~nm}$, essentially assembled into a tablet meso-crystals ([Rousseau et al., 2005a], [Wohlrab et al., 2005] and [Kulak et al., 2007]). The growth-ring structures observed in this study most likely plays a key role in the transformation from ACC precursor in the surrounding hydro-gel to the formation of aragonite nano-domains as postulate earlier (Weiss et al., 2002). The foam-like, intra-crystalline organic material, in which the aragonite meso-crystals are embedded, must be similar in composition to the organic material that makes up the growth-ring, from which it is inherited. We postulate that the growth dynamics of nacre tablets is controlled by spatially distinct components of acidic proteins in the growth-ring and in the adjacent hydro-gel reservoir supplying the ACC precursor component. In the hydro-gel, proteins that inhibit calcium carbonate crystallization are dominating, whereas in the growth-ring, aragonitenucleating proteins are dominant. In the growth-ring, the ACC precursor phase crystallizes into nano-crystals (i.e. about $50 \mathrm{~nm}$ in size) and are added to the growing tablet. This dynamic situation poses several challenges. First, the hydro-gel precursor phase has to be continuously produced from the mantle and transferred to the constantly emerging medium beneath the top membrane where new tablets are about to form. Observations of mineral (presumably ACC) containing granules in the cytoplasm of the mantle (Neff, 1972) suggest that ACC, indeed perhaps the entire hydro-gel phase, might be synthesized in the mantle and secreted to the space below the membrane. Second, because the aragonite-nucleating proteins and other organic materials in the growth-ring are transferred to the tablets in which they embed the nano-scale aragonite crystals, the growth-ring is continuously consumed and has to be replaced during tablet growth. This requires either that (1) the aragonite-nucleating proteins of the growth-ring are scavenged from the surrounding silk-phase, presumably by electrostatic forces that can preferentially attract molecules with high acidity, or (2) that these components are delivered directly from the mantle to the growth-ring. Isotopic labelling experiments designed to trace different organic constituents in the mantle and in the nacre-forming compartment might help distinguish between these two different scenarios.

\section{Conclusion}

A growth-ring structure, rich in organic materials, surrounds each growing nacre tablet during formation of sheet nacre in P. margaritifera bivalves. This structure disappears as nacre tablets grow laterally and collide with adjacent tablets. It is conceivable that this organic ring structure acts to nucleate aragonite into the highly oriented nano-crystals ( $\sim 50 \mathrm{~nm}$ in size) that make up the meso-crystal (i.e. $\mu \mathrm{m}$ sized) nacre tablets ([Wohlrab et al., 2005] and [Kulak et al., 2007]). This adds support for a highly dynamic biomineralization process during which organic materials and carbonate precursor phases (likely amorphous) are delivered to the site of nacre tablet formation from the overlying mantle with a high degree of spatial control.

\section{Acknowledgments}

We thank Tahiti Perles for technical and financial support. This work was granted by the Agence Nationale de la Recherche Française under the awards ANR Blan06-3_135480: Nacre Fluid and ANR-05-JCJC-0158: NanoGeoBio. We thank Gérard Mascarel for his help in the electron microscopy work (Service commun de microscopie électronique des Sciences de la Vie du MNHN). Lia Addadi, Steve Weiner (Weizmann Institute of Science) and Rory Arrowsmith are thanked for constructive discussions. Thanks are also due to Francine Lallier 
and Sandrine Borzeix for their assistance in preparing this manuscript. Two anonymous reviewers are thanked for highly constructive criticism.

\section{References}

Addadi et al., 2003 L. Addadi, S. Raz and S. Weiner, Taking advantage of disorders: amorphous calcium carbonate and its roles in biomineralization, Adv. Mater. 15 (2003), pp. 959-970.

Addadi et al., 2006 L. Addadi, D. Joester, F. Nudelmann and S. Weiner, Mollusk shell formation: a source of new concepts for understanding biomineralization processes, Chemistry 12 (2006), pp. 980-987.

Anon,, 2006 Anon, Golay’s global view, Pearl World: Int. Pearling J. 15 (2006), pp. 7-8.

Bevelander and Nakahara, 1969 G. Bevelander and H. Nakahara, An electron microscope study of the formation of nacreous layer in the shell of certain bivalve molluscs, Calc. Tiss. Res. 3 (1969), pp. 84-92.

Caseiro, 1995 J. Caseiro, Evolution of deposit thickness of organic and aragonitic material during the growth of P. margaritifera pearls, C.R. Acad. Sci. Paris 321 (1995), pp. 9-16.

Checa et al., 2006 A.G. Checa, T. Okamoto and J. Ramirez, Organization pattern of nacre in Pteriidae (Bivalvia: Mollusca) explained by crystal competition, Proc. R. Soc. B 273 (2006), pp. 1329-1337.

Checa and Rodriguez-Navarro, 2005 A.G. Checa and A. Rodriguez-Navarro, Selforganisation of nacre in the shells of Pterioida (Bivalvia: Mollusca), Biomaterials 26 (2005), pp. 1071-1079.

Cohen, 2003 Cohen, O., 2003. The influence of a gel environment on calcium carbonate biomineralization. M.Sc. Thesis, Weizmann Institute of Science, Rehovot (Israel).

Currey, 2005 J.D. Currey, Hierarchies in biomineral structures, Science 309 (2005), pp. 253254.

Dauphin et al., 2008 Y. Dauphin, A.D. Ball, M. Cotte, J.-P. Cuif, A. Meibom, M. Salomé, J. Susini and C.T. Williams, Structure and composition of the nacre-prisms transition in the shell of Pinctada margaritifera (Mollusca, Bivalvia), Anal. Bioanal. Chem. 390 (2008), pp. 1659-1669.

Gehrke et al., 2005 N. Gehrke, N. Nassif, N. Pinna, M. Antonietti, H.S. Gupta and H. Cölfen, Retrosynthesis of nacre via amorphous precursor particles, Chem. Mater. 17 (2005), pp. 6514-6516.

Istin and Girard, 1970 M. Istin and J.P. Girard, Dynamic state of calcium reserves in freshwater clam mantle, Calc. Tiss. Res. 5 (1970), pp. 196-205. 
Kulak et al., 2007 A.N. Kulak, P. Iddon, Y. Li, S.P. Armes, H. Cölfen, O. Paris, R.M. Wilson and F.C. Meldrum, Continuous structural evolution of calcium carbonate particles: a unifying model of copolymer-mediated crystallization, J. Am. Chem. Soc. 129 (2007), pp. 3729-3736.

Levi-Kalisman et al., 2001 Y. Levi-Kalisman, G. Falini, L. Addadi and S. Weiner, Structure of the nacreous organic matrix of a bivalve mollusk shell examined in the hydrated state using Cryo-TEM, J. Struct. Biol. 135 (2001), pp. 8-17

Lowenstam, 1981 H.A. Lowenstam, Minerals formed by organisms, Science 211 (1981), pp. $1126-1131$.

Meibom et al., 2004 A. Meibom, J.P. Cuif, F. Hillion, B.R. Constantz, A. Juillet-Leclerc, Y. Dauphin, T. Watanabe and R.B. Dunbar, Distribution of magnesium in coral skeleton, Geophys. Res. Lett. 31 (2004), p. L23306.

Meibom et al., 2007 A. Meibom, S. Mostefaoui, J.-P. Cuif, Y. Dauphin, F. Houlbreque, R.G. Dunbar and B. Constanz, Biological forcing controls the chemistry of reef-building coral skeleton, Geophys. Res. Lett. 34 (2007), p. L02601.

Mutvei, $1979 \mathrm{H}$. Mutvei, On the internal structures of the nacreous systems tablets in molluscan shells, Scanning Electron Microsc. II (1979), pp. 457-462.

Nassif et al., 2005 N. Nassif, N. Pinna, N. Gehrke, M. Antonietti, C. Jäger and H. Cölfen, Amorphous layer around aragonite platelets in nacre, PNAS 102 (2005), pp. 12653-12655.

Neff, 1972 J.M. Neff, Ultrastructure of the outer epithelium of the mantle in the clam Mercenaria mercenaria (L) in relation to calcification of the shell, Tissue Cell. 4 (1972), pp. 591-600.

Nudelman et al., 2006 F. Nudelman, B.A. Gotliv, L. Addadi and S. Weiner, Mollusk shell formation mapping the distribution of organic matrix components underlying a single aragonitic tablet in nacre, J. Struct. Biol. 153 (2006), pp. 76-187.

Nudelman et al., 2008 F. Nudelman, E. Shimoni, E. Klein, M. Rousseau, X. Bourrat, E. Lopez, L. Addadi and S. Weiner, Environmental- and cryo-scanning electron microscopy study of the forming nacreous layer from the shells of the bivalves Atrina rigida and Pinctada margaritifera, J. Struct. Biol. 162 (2008), pp. 290-300.

Rousseau et al., 2005a M. Rousseau, E. Lopez, A. Couté, G. Mascarel, D. Smith, R. Naslain and X. Bourrat, Sheet nacre growth mechanism: a Voronoi model, J. Struct. Biol. 149 (2005), pp. 149-157.

Rousseau et al., 2005b M. Rousseau, E. Lopez, P. Stempflé, M. Brendlé, L. Franke, A. Guette, R. Naslain and X. Bourrat, Multi-scale structure of sheet nacre, Biomaterials 26 (2005), pp. 6254-6262.

Snow and Pring, 2005 M.R. Snow and A. Pring, The mineralogical structure of shells: Part 2. The iridescence colors of abalone shells, Am. Mineral. 90 (2005), pp. 1705-1711. 
Stolarski and Mazur, 2005 J. Stolarski and M. Mazur, Nanostructure of biogenic versus abiogenic calcium carbonate crystals, Acta Palaeontol. Pol. 50 (2005), pp. 847-865.

Towe and Hamilton, 1968 K.M. Towe and G.H. Hamilton, Ultrastructure and inferred calcification of the mature and developing nacre in bivalve mollusks, Calc. Tiss. Res. 1 (1968), pp. 306-318.

Wada, $1958 \mathrm{~K}$. Wada, The crystalline structure on the nacre of the pearl oyster shell, Bull. Jpn. Soc. Sci. Fish. 24 (1958), pp. 422-427.

Wada, 1961 K. Wada, Crystal growth of molluscan shells, Bull. Nat. Pearl Res. Lab. 7 (1961), pp. 703-828.

Weiner and Addadi, 1997 S. Weiner and L. Addadi, Design strategies in mineralized biological materials, J. Mater. Chem. 7 (1997), pp. 689-702

Weiss et al., 2002 I.M. Weiss, N. Tuross, L. Addadi and S. Weiner, Mollusc larval shell formation: amorphous calcium carbonate is a precursor phase for aragonite, J. Exp. Zool. 293 (2002), pp. 478-491.

Wohlrab et al., 2005 S. Wohlrab, H. Cölfen and M. Antonietti, Crystalline, porous microspheres made from amino acids by using polymer-induced liquid precursor phases, Angew. Chem. Int. Ed. 44 (2005), pp. 4087-4092. 


\section{Figures}
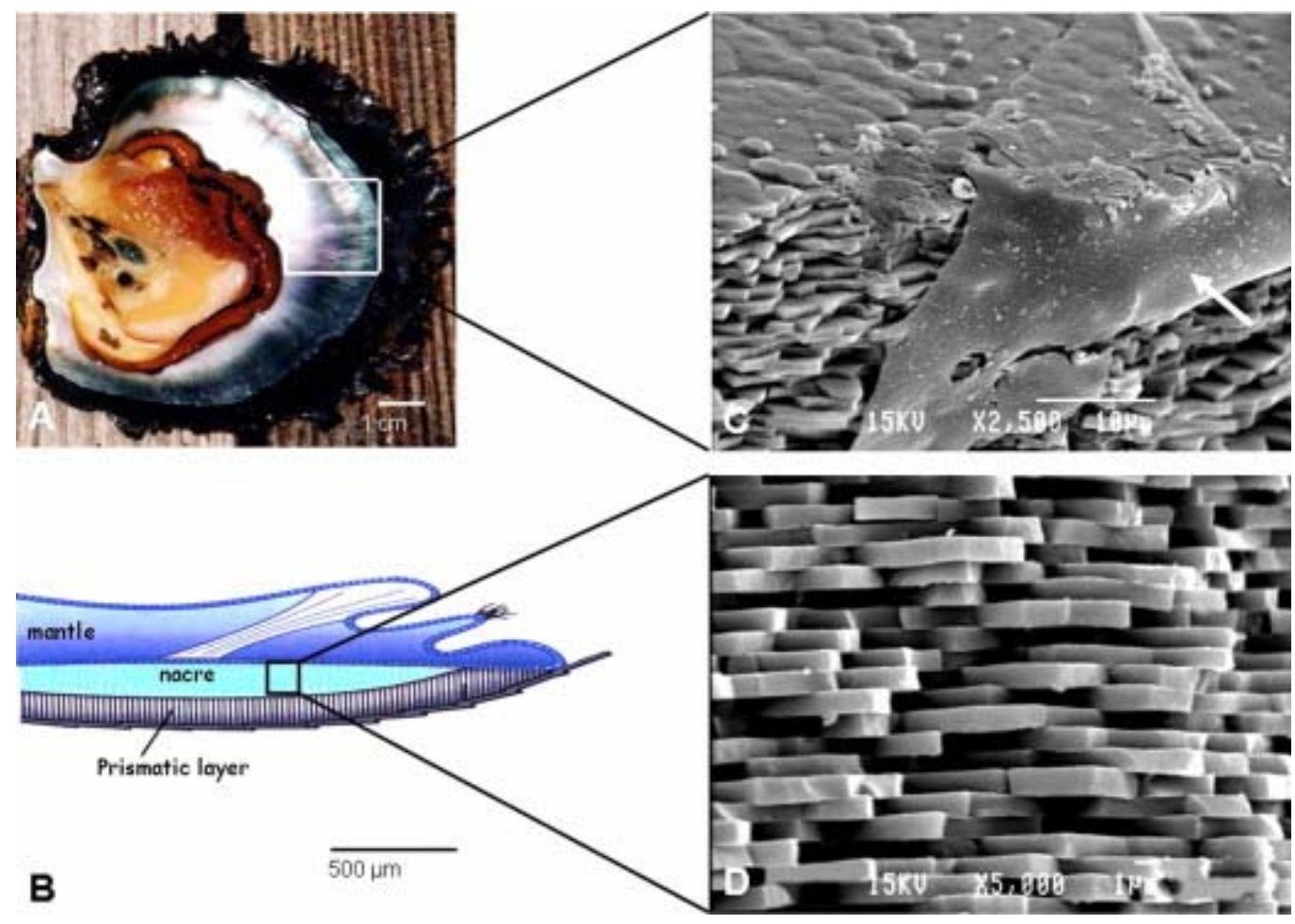

Fig. 1. The shell of the pearl-producing Pinctada margaritifera oyster. (A) An opened shell in which the animal is still in place. The brighter nacreous layer of aragonite is clearly visible next to the animal. The nacreous layer coats the darker, prismatic shell of calcite that forms the outer shell. During nacre formation the tissue of the animal, the so-called 'mantle', reaches out to the transition between nacre and calcitic shell where new nacre is formed. (B) Schematic representation of the shell structure and the overlying mantle of the animal. (C) Careful removal of the mantle, which is in direct contact with the shell growing surface reveals the surface membrane covering the forming nacre tablets (white arrow) after mechanical fractures of the nacre. (D) Fracture of the shell reveals the brick-and-mortar structure of the nacreous layer. Each layer is about $0.5-1 \mu \mathrm{m}$ thick. 

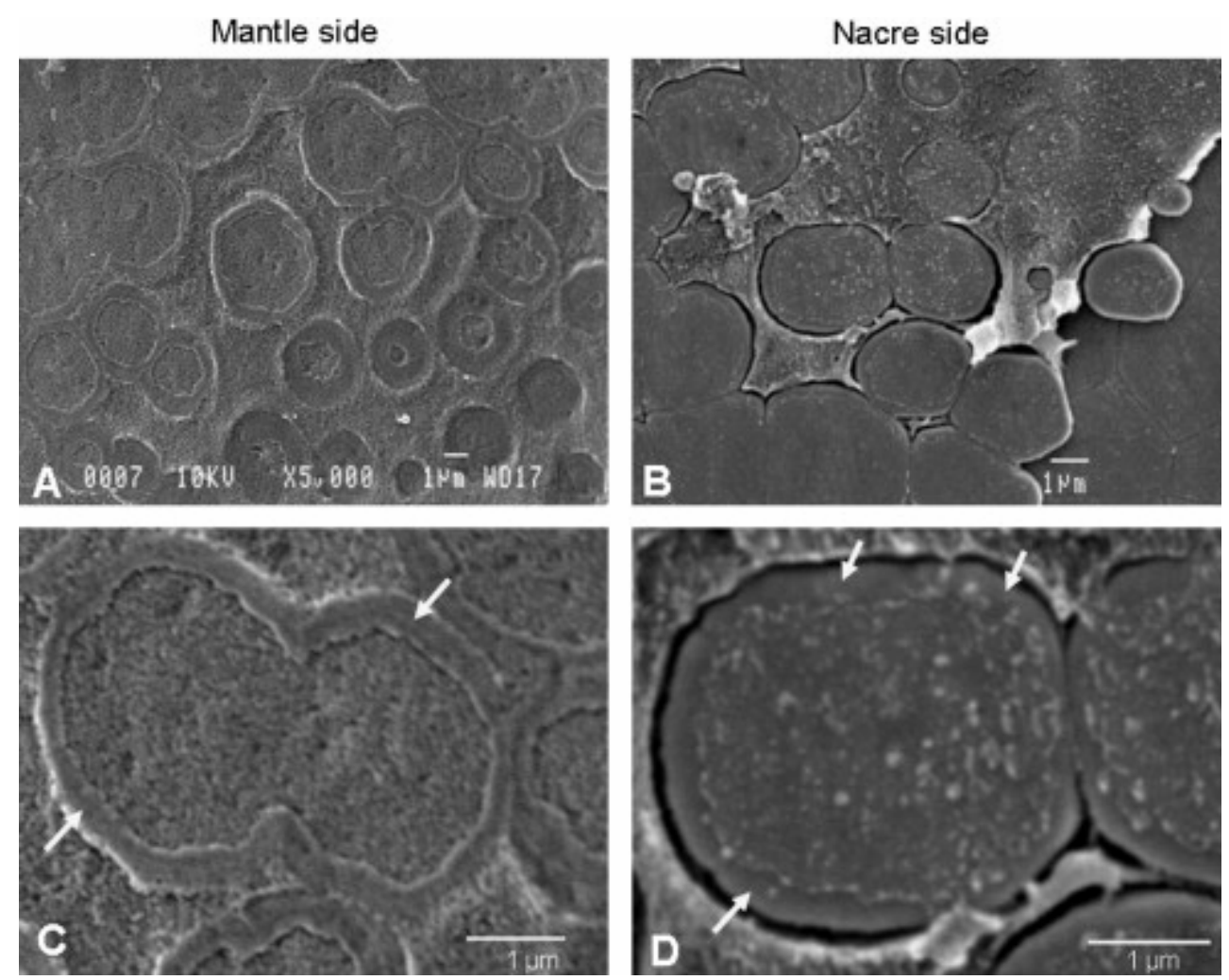

Fig. 2. The mantle-nacre interface. Electron microscopy images of structures on the mantle side (A and C) and corresponding structures on the surface of the growing nacre tablets (B and D). These two surfaces are in direct contact during nacre formation. Distinct ring structures surround each nacre tablet (D, white arrows) and have morphologically complementary features in the membrane on the mantle side (C, white arrows). This ring disappears when tablets collide during lateral expansion (C and D). See text for discussion. 

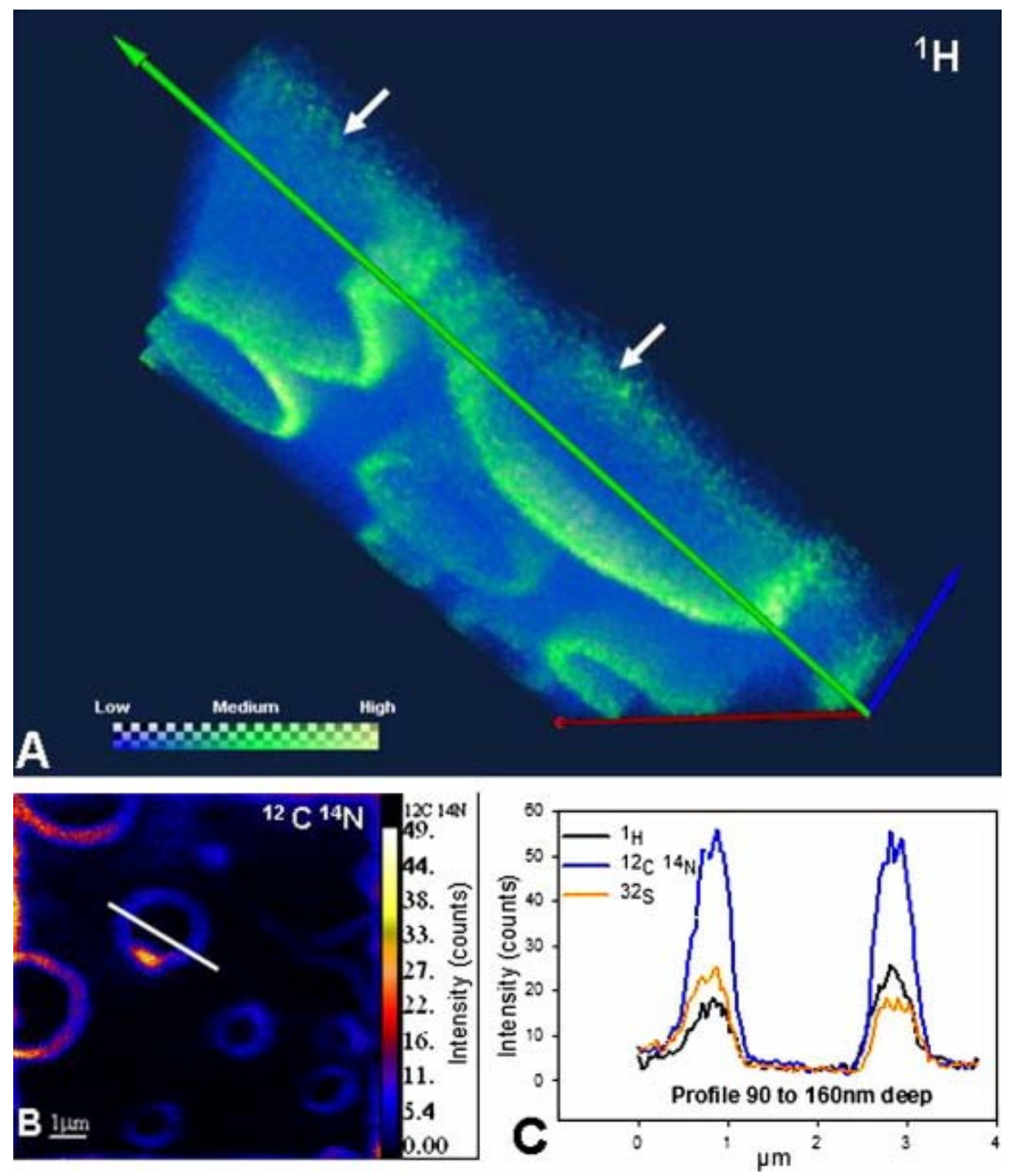

Fig. 3. Distribution of organics around nacre tablets. (A) A 3-dimensional reconstruction of the $\mathrm{H}$ distribution at different depths in the surface layers of the forming nacre. The data were obtained with the NanoSIMS ion microprobe. The direction of sputtering is indicated by a white arrow. The sputtered volume is about $10 \mu \mathrm{m} \times 10 \mu \mathrm{m} \times 0.2 \mu \mathrm{m}$. For greater clarity, the thickness of this volume (blue axis) has been expanded by a factor of 6 . The surface membrane is visible in the first images (white arrow) but deeper in the structure organics are concentrated only in the growth-rings surrounding each nacre tablet. (Full 3-D reconstructions of the H, N and S distributions are available in SD as movies). (B) NanoSIMS image showing the distribution of $\mathrm{N}$, which is also preferentially concentrated in the growth-ring around each nacre tablet. (C) Line-profile (track indicated in B) showing the enhanced concentrations of $\mathrm{H}, \mathrm{N}$, and $\mathrm{S}$ in the growth-ring. See text for discussion. (For interpretation of the references to colour in this figure legend, the reader is referred to the web version of this article.) 


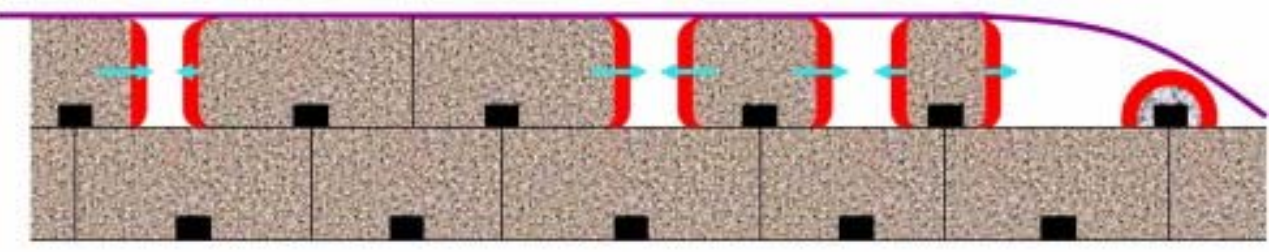

B

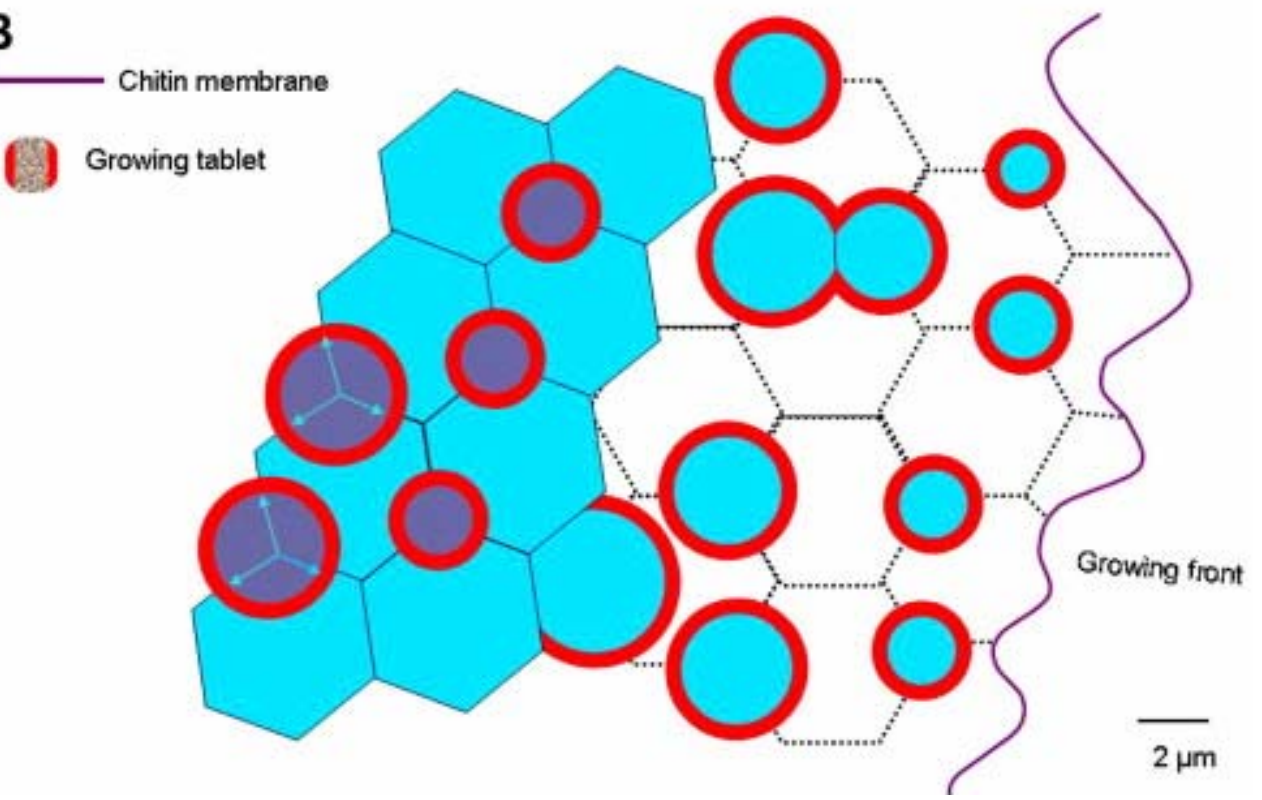

Fig. 4. Schematic representation of the nacre tablet growth-model. (A) Side-view of the topmost tablet layers. Underneath the top membrane, which is in direct contact with the overlying mantle of the animal, individual tablets grow laterally from a carbonate-charged silk-phase through crystallization mediated by organics in the nucleation sites (black rectangles) and in the growth-rings (shown in red). The nucleation sites are generally placed above the junctions of three tablets in the underlying layer of tablets. When two tablets collide during growth, the growth-rings first merge and subsequently disappear, allowing adjacent tablets to make physical contact. (B) Top view of the nacre growth front. Individual tablets nucleate and grow concentrically reflecting the shape of the surrounding organic growth-ring. Only after collision and disappearance of the growth-rings do individual tablets take the form of hexagons. The hexagonal geometry of individual tablets is therefore the result of the distribution of nucleation sites, which inherit their distribution from the underlying layer. (For interpretation of the references to colour in this figure legend, the reader is referred to the web version of this article.) 


\section{Supplementary Material for Dynamics of Sheet Nacre Formation in Bivalves}

Marthe Rousseau $^{\mathrm{a}^{*}}$, Anders Meibom $^{\mathrm{b}}$, Marc Gèze $^{\mathrm{c}}$, Xavier Bourrat $^{\mathrm{d}}$, Martine Angellier ${ }^{\mathrm{d}}$, Evelyne Lopez $^{\mathrm{e}}$

${ }^{\text {a } U M R ~} 7561$ CNRS-Nancy University, BP 184, 54505 Vandoeuvre les Nancy, France

${ }^{\mathrm{b}}$ National Museum of Natural History, LEME, 61, rue Buffon, 75005 Paris, France

${ }^{\mathrm{c}}$ National Museum of Natural History, USM 504, 61, rue Buffon, 75005 Paris, France

${ }^{\mathrm{d}}$ Université d'Orléans, Université François Rabelais - Tours, CNRS/INSU

Institut des Sciences de la Terre d'Orléans - UMR 61136 Campus Géosciences

1A, rue de la Férollerie 645071 Orléans cedex 2 France

e National Museum of Natural History, BOME, 43 rue Cuvier, 75005 Paris, France

*To whom correspondence should be adressed. E-mail: rousseam@gmx.net;

\section{Material and methods}

\section{Scanning Electron Microscopy}

Observations were performed at the Common Service of Electronic Microscopy of the laboratories of the Life Sciences, National Museum of Natural History (France) with a JEOL JSM-840A operating at $15 \mathrm{kV}$, at the Weismann Institute of Science, Rehovot (Israel) with a high-resolution Ultra 55 Zeiss using an in-lens secondary electron detector, at the University of Orléans (France) with a Hitachi 4500 FEG SEM at 3kV with an in-lens detector. 


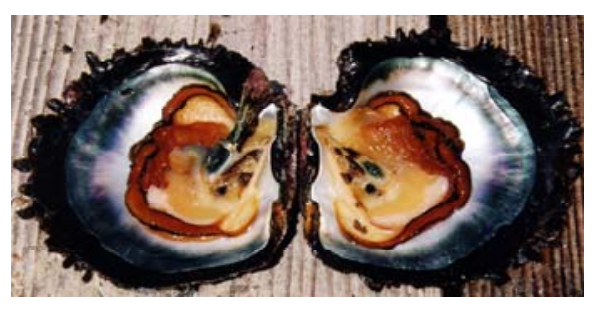

\section{$\downarrow \begin{aligned} & \text { Ethanol fixation } \\ & \text { Dehydration }\end{aligned}$}

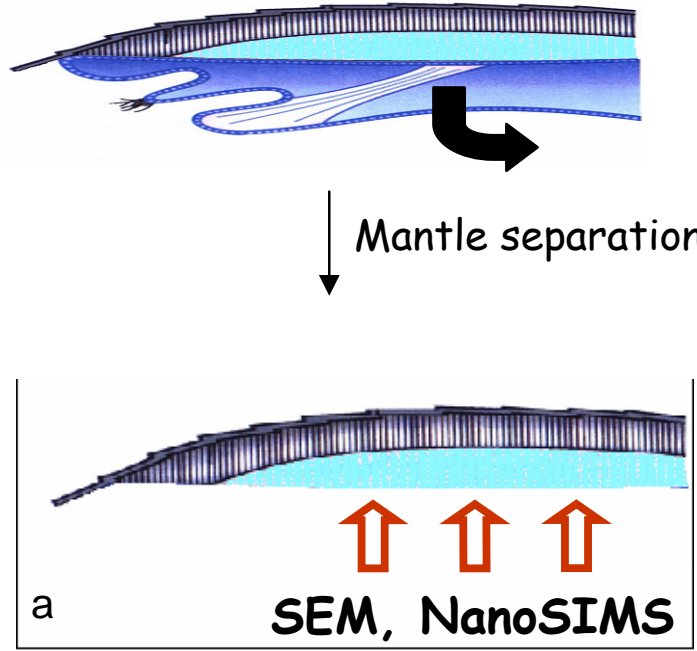

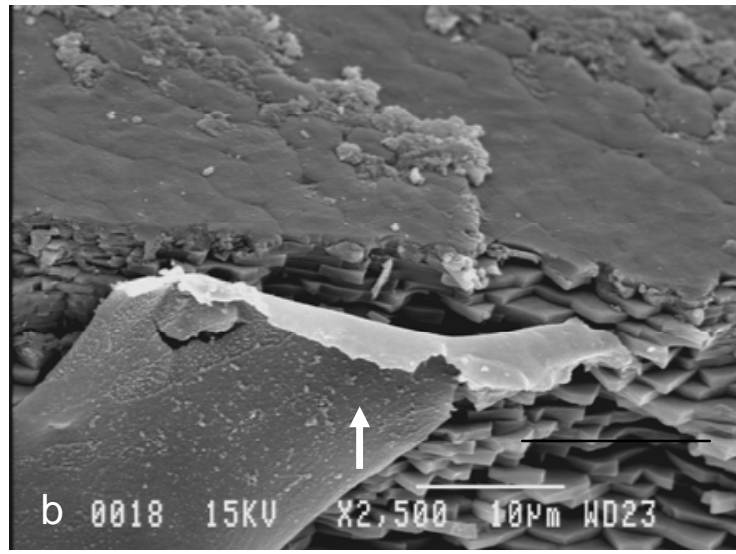

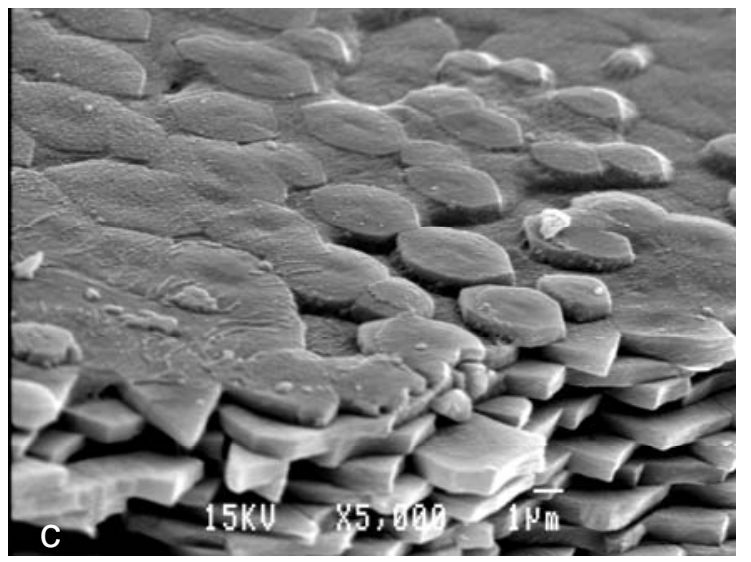

Supp-Fig. 1. Preparation of growing shell surfaces. (a) Pinctada margaritifera oysters were sacrified and fixed. The mantle, which is in direct contact with the shell growing surface, was removed. The surface membrane kept in place (b, white arrow) in some specimens and in other specimens, the membrane was removed (c).

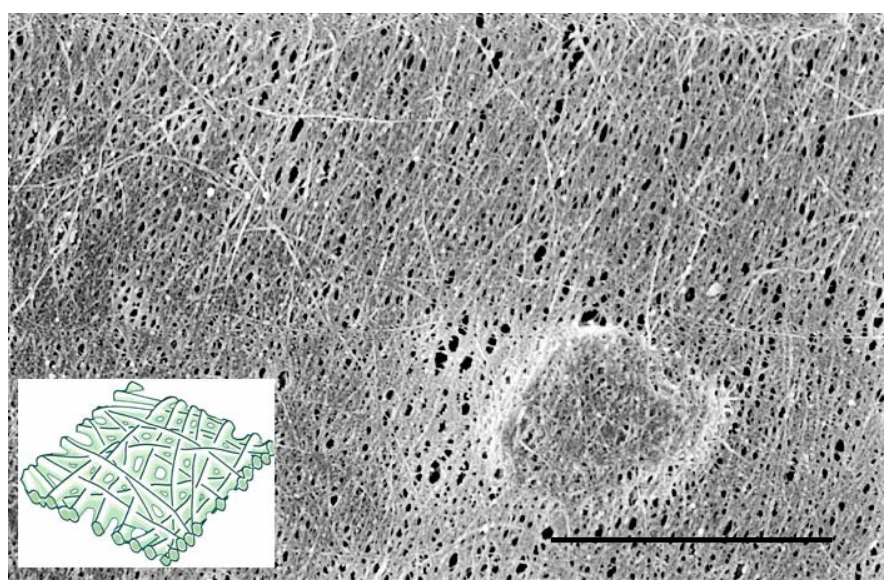

Supp-Fig. 2. SEM image of the nacre growth front in Pinctada margaritifera showing the growing aragonite tablet covered by a sheet of organic matrix: fine structure of the chitinbased membrane $($ bar $=5 \mu \mathrm{m})$. The image is courtesy of Fabio Nudelman from the Weizmann Institute of Science, Rehovot (Israel). 


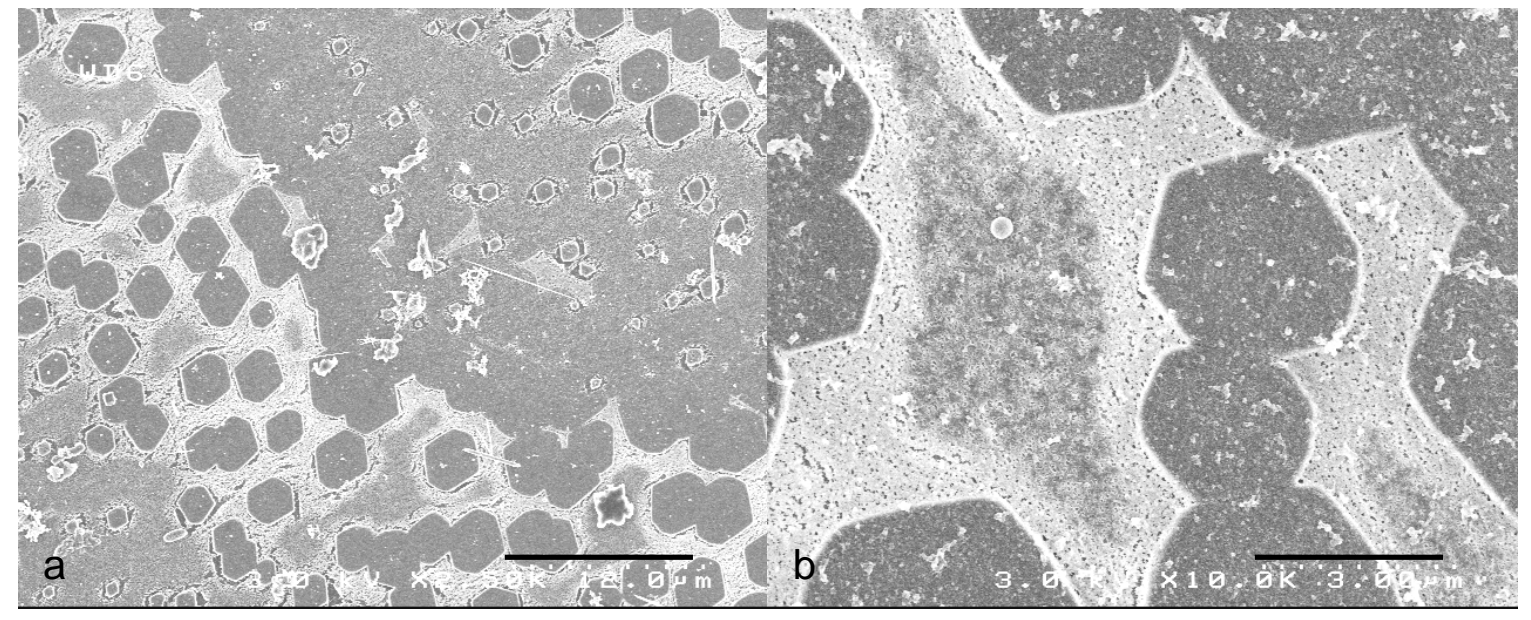

Supp-Fig. 3. Direct observation of nacre growing compartment surface on shell side at low magnification (a, scale bar $=12 \mu \mathrm{m}$ ) and higher magnification $(\mathrm{b}$, scale bar $=3 \mu \mathrm{m})$. The samples were fixed in 70\% ethanol and progressively dehydrated. Supp-Fig. 3 shows that the organic material keeps in place and appears white in SEM at low energy.
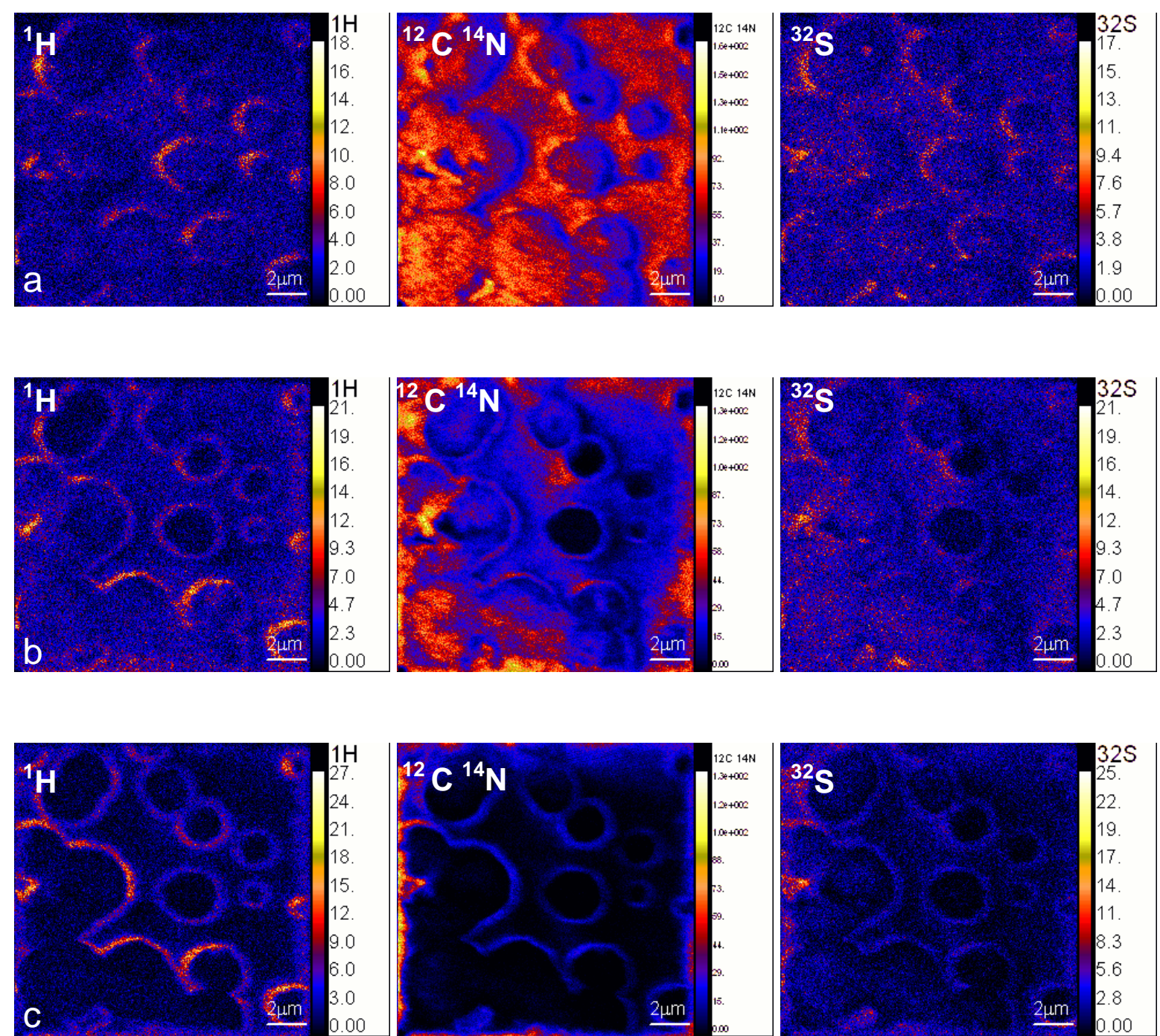
Supp-Fig. 4. Distribution of organics in growing nacre. The distribution of $\mathrm{H}, \mathrm{N}$, and $\mathrm{S}$ imaged with the NanoSIMS at the very surface of the growing nacre (row $a$ ), at depths of about $100 \mathrm{~nm}$ (row $b$ ) and at a depth of about $200 \mathrm{~nm}$ (row $c$ ). The organic-rich ring surrounding each tablet is clearly visible once overlying material has been removed (row $c$ ).

\section{Amira}

Image 3D reconstruction and visualisation of 25 stacked planes of NanoSIMS images was produced with Amira software (ver 4.1.1) from TGS Mercury Computer System using the voltex module. This direct volume rendering technique is an intuitive method for visualizing 3D scalar fields in which each point in the data volume is assumed to emit and absorb light. The amount and colour of emitted light and the amount of absorption are determined from the scalar data by using a colourmap that incorporates a factor to change the overall transparency of the object independent of the data value.

\section{NanoSIMS sputter 3D volume reconstruction (movies in mpg format):}

- Rousseau_3D_H.mpg

- Rousseau_3D_N.mpg

- Rousseau_3D_S.mpg 